\title{
A STUDY OF STYLE AND STYLISTICS IN FARLEY MOWAT'S PEOPLE OF THE DEER
}

\author{
Denish Raja Duari ${ }^{1}$, G. Baskaran ${ }^{2}$, Evan Afri ${ }^{3}$ \\ The Gandigram Rural University, Gandigram - 624 302, Dindigul District, Tamil Nadu, India. \\ The Gandigram Rural University, Gandigram- 624 302, Dindigul District, Tamil Nadu, India. \\ Politeknik Ganesha Medan, Medan, Indonesia \\ denishdurai@gmail.com
}

Submitted: 08/12/2021

Accepted: 17/12/2021

Publication: $17 / 12 / 2021$

\begin{abstract}
The article attempts to evaluate Farley Mowat's People of the Deer in terms of style and stylistic perspectives. Mowat (1921- 2014) is a well-known Canadian author. In the usage of the language resource, he has exhibited an excellent degree of competency. His styles of writing were an autobiographical fashion. With regard to linguistic and literary styles, the study examined style and stylistic trends. The researcher suggests that the study would be helpful for the students of linguistics and literature in future. This study will not provide a detailed description of all stylistic devices; rather, it will provide a picture of the traditional flouted as well as variations that Mowat has introduced. Style, Stylistics, Alliteration, Repetition, Collocation, and so on are all examples of major literary and linguistic stylistics.
\end{abstract}

Keywords: Grammar Function, Language, Mowat, Style, Stylistics, People of the Deer,

\section{Introduction}

A study of a literary text can be approached in a variety of ways. We may look at literary texts from a variety of perspectives, including personal, social, psychological, historical, and cultural. Furthermore, Structuralism, Post-Structuralism, Marxism, Historicism, DeConstruction, Post-Modernism, Feminism, Post-Colonial Criticism, Narratology, and Stylistics can also be considered. This above can be divided into two categories: thematic and linguistic approaches. The goal is to show how stylistics may be used in the study of literary texts. Stylistics investigates literary writings using linguistic approaches and insights. It presents empirical evidence to back up inferences regarding literary works. On the basis of linguistic data, it proposes fresh interpretations of literary texts. It clarifies how literary meanings are constructed. In the understanding and appreciation of literary texts, stylistics is extremely important.

This article studies a Style and Stylistics analysis of Mowat's People of the Deer. This will be a substantial use to language and literary instructors, scholars, as well as to those concerned with the author in a specific study. It will be useful in terms of appreciating the literary discourse's innovative use of language.

The word 'style' came to English from the Latin stylus which indicated a sharp-pointed pin or device for scribbling on wax slabs; eventually, it denoted one's writing style; and presently, it implies way, expression, and trend. Originally, the phrase Stylus exercitatus (practiced style) meant ability in controlling the instrument and hence referred to fine calligraphy. The term 'style' has numerous connotations and may be defined in a variety of ways. It has several meanings both outside and within each work of art. Style could be defined as the art of expressing oneself through writing. 

mentioned:

According to Abrams and Harpham 's A Handbook of Literary Terms (2009)

Style has traditionally been defined as the manner of linguistic expression in prose or verse - as how speakers or writers say whatever it is that they say. The style specific to a particular work or writer, or else distinctive of a type of writings, has been analyzed in such terms as rhetorical situation and aim; the characteristic diction, or choice of words; the type of sentence structure and syntax; and the density and kinds of figurative language. (297)

A style is a distinctive use of language - Chomsky observes, and "it is difficult to see how the uses of a system can be understood unless the system itself has been mapped out" (3). The style could be used in the field of writing to communicate ideas and even problems by an author who understands how to express his thoughts with more precision and clarity. In other words, inside a narrative text, we may find something distinctive and unique to the writer, poet, or novelist... for example, an author's work might be regarded to be a mirror of his own character. Also, "style is writer's individual way of feeling and seeing will compel an individual way of using language" (13).

The style of literature differs from that of linguistics. Linguists and literary critics do not view the matter in the same way. "To the former, the investigation of style is essentially a scientific description of certain types and sets of linguistic structures that occur in a given text, and of their distribution. The literary critic will be interested in textual stimuli or aesthetic effect which recalls some past experience of the reader" (4).

Comprehensively, stylistics is the detailed examination of a literary work from both literary and linguistic perspectives. It uses the linguistic tool to evaluate the aesthetic style of creative work. Linguistics traces the conceptual system of language and offers stylistics with the theoretical perspectives and analysis techniques needed to understand the style of a writer. Stylistics is the intermediary discipline since it is associated with both literary criticism and linguistics. Because of its strong linguistic foundation, it is more scientific in its observation, evaluation, and study of literary texts. And for its connection to linguistics, stylistics may be significant to literary criticism. Linguistic stylistics may supply particular data as well as analytical tools. Accuracy of facts and deep influence with the mechanisms of Language would be dependable on working out our speculations about the Language of any literary text.

The language of literature encompasses more than just stylistics; it may also be used for explanatory prose, public addresses, advertisements, and etc. Style can refer to a person's way of expressing themselves, such as when they perform, draw, dance, or act. Therefore, in the largest sense, every human action can fall within the purview of stylistics. Because language is subject to variability, style may differ from one environment to the next. That is why we talk of Shakespearean, Miltonian, Elizabethan, Victorian, Wordsworthian, Eliotian, and other epic styles. Style, whether literary or non-literary, may thus be understood as a variety in the use of words.

The focus of stylistics is the carefully chosen component of a specific language. It can cover a wide range of terminology and genres, either spoken or written. As style is an inextricable aspect of language, it manifests itself in a number of ways. Scientific terminology, medicinal terminology, and business registrations are all discussed. The basic objective of stylistics is to investigate the literary style of creative writing and to explain the practical language aspects of a work that influence its deeper meaning and significance. It highlights the link between common and literary language, and it discusses technical features of the text's language, including grammatical constructions, before applying this information to the analysis.

According to Peter Barry, the goal is to move from sentence grammatical structure to textual grammatical, which considers how text functions as a whole to accomplish its goals. It also justifies the facts about how literature impacts are achieved through the use of different linguistic aspects. It shows the link between the text and the context, allowing for a better understanding and respect of the writer's accomplishments.

There are various opinions on style and stylistics highlights the linguistic surface of a work of art and affects our sentiments and perception, and also that are where the style of that 
particular literary text lives. Stylistics investigates and evaluates the text's language. Because a work of art is expressed in language, stylistics or linguistic criticism is a method of approaching literature or literary texts through language. Stylistics is the systematic and accurate examination and analysis of a text. As the language of the text, stylistics, as a linguistics-based and linguistics-oriented discipline, needs to be scientific, analytical, and methodical in its examination. The author tries to influence the text's language for his stylistic purposes, resulting in a one-of-a-kind effect. The stylistics studies many such characteristics of language and literary style, providing explicitly what would otherwise be implied.

Stylistics serves as a link between the disciplines of literature and language since it adds between both. It, then, is a method of analyzing text. Surely, when literary critics consider literature, they must consider style first. In some ways, the conventional view of stylistics is the contemporary version of the ancient practice known as 'rhetoric,' which has been evolved as the art of speaking effectively in public but eventually expanded to encompass the concept of brilliance, whether spoken or written. The method of classical rhetoric was the authoritarian and limited style to a decoration standing separate from the writer and his or her subject, although the style was seen as an element of the process of argument. As a result of this, style is restricted to specific rhetorical figures like simile, metaphor, personification, oxymoron, and the like.

Usually, the author's style is distinct in its own right. Their vocabulary may vary depending on the genre or situation, but they have a particular style of their own. They have a distinct impression on everything they write, and that is their style. In Theory of Literature (1949), the advocates of structuralism Rene Wellek and Austin Warren, together with New Criticism, brought out that literature is a linguistic substance, and language is its natural resource at all levels. According to them, studying literature from a linguistic perspective is a scientific approach that may support a student or critic in tracing specific aspects of the particular style in a work.

In his final remark, Linguistics and Poetics, Jakobson (1958) made the most valuable addition. He emphasized the importance of linguistics in stylistic research, arguing that language should be analyzed in terms of its various functions such as emotive, connotative, referential, multilingual, and poetic. To sum up, the writings of Eliot, Pound, Joyce, Wellek, Jakobson, and others have made significant contributions to the language of the text, setting the path for the formation of stylistics as a field.

With the development of linguistics, stylistics studies have grown more objective, and the way people think about style has shifted as well. In Thomas Sebeok's Style in Language (1960), the findings of the renowned conference on style held at Indiana University in Bloomington in 1958 were published, and stylistic became acknowledged as a subject with its own right. Stylistics, as a scientific subject, strives to provide a methodical, accurate, and independent account of a writer's or discourse's style. As a result, style may be defined as the art of communication, and stylistics as the study of style.

Farley Mowat (1921-2014) was a well-known Canadian writer and environmentalist. He has a long history of writing on the environment with seriousness and enthusiasm. Most of his writings are focused on wildlife species. His major interest is the environment, which is why he has developed a fondness for the outdoors. His concept of nature as a valuable, God-given resource that transcended utilitarian value contributed to the formation of today's environmental space and ecological movements. Mowat has demonstrated a high level of proficiency in the use of the language resource. He writes in the style of an autobiographical fashion.

Considering his exactness, Mowat's language is hardly sophisticated. He does not use large, technical terminology that is difficult to comprehend, and he conveys it clearly and concisely. As a writer, this is one of his most valuable assets. His work has a strong linguistic knowledge. It is clear from Mowat's works that he has successfully represented the conventional Canadian attitude. His writing career started off with People of the Deer (1952), the story established him as a controversial figure. It was followed by Lost in the Barrens (1956), a best children's book received the Governor's General Award. Owls in the Family (1962), Never Cry Wolf (1963), A Whale for the Killing (1972), And No Bird Sang (1979), Sea of Slaughter (1984), Born Naked (1993), No Man's River (2004), Eastern Passage (2010) are some of his wellknown works. 
Mowat's autobiography People of the Deer brought him critical acclaim. The narrative depicted the struggles and existence of the Ihalmuit, an Inuit Eskimo community that resided in the Arctic Barren Lands and was primarily reliant on the region's vast caribou herds. The Ihalmuit lived in harmony with nature, yet they were on the verge of extinction. Mowat stays with them for two years. He studied and comprehended their pitiful situation.

Mowat is a remarkable storyteller cum stylist. His narratives and tales are quick and fascinating, regardless of the situation, and his style is elegant, personalized, and engaging. Responsibilities to principles elicit linguistic explosions, whereas his passion produces artistic language and striking visuals. Lexical items, idiomatic phrases, colloquial expressions, verb employment, multimodal auxiliaries, and punctual structures are among his several expressions.

Linguistic playfulness has been discovered to remain active at all times. A passion for neologism (coining new words) is one way it emerges. Mowat is filled with new coinages. Different processes can yield content words, including nouns, verbs, adverbs, and adjectives, which can be used to build new verbal structures and colloquial expressions. Frequently, in Mowat, two adjectives are combined with hyphens to form a new compound adjective. For instance, "without bends to relieve the heavy-footed pace" (Mowat 2) "that river was the longlegged shape of a deer" (Mowat 3).

Mowat is particularly fond of descriptive adjectives, and he utilizes them in both predictive and attributive contexts. Here are a few instances from the text e.g. senseless, illusory, restless, indestructible, dusty, flat, seedy, tantalizing, etc.

Adverb occupies the highest position in the sentences of Mowat's People of the Deer. The following examples will elucidate this notion further. E.g. failed disastrously, simultaneously rusty, completely gripped, unhurriedly engrossed, desperately seeking, yearly pilgrimages, gyrated foolishly, stumbled helplessly, etc.

In Mowat's People of the Deer, alliteration takes first place in the phrases. A literary method in which a sequence of words begins with the same consonant sound is known as alliteration. It is employed to highlight an essential point that a writer or speaker wants to make. Take a look at the following examples:
1. The Why and Wherefore
2. The Lifeblood of the Land
3. $\boldsymbol{F}$ east and $\boldsymbol{F}$ amine
4. Stone Men and Dead Men
5. he stretched the hands of his soul

'Word transfer' with meaning is another essential feature in Mowat's approach. Because of its forcefulness, he appears to like this formulation. Its appearance in the text is noteworthy therefore, we should pay attention to it from a stylistic perspective. The contextual importance of the cases may be seen. This style is partly like Epanalepsis e.g. in his preface to the text
1. I sat beside a man who was not of my race
2. The man who sat beside me started over the
3. $\quad$ The man beside me was no longer there
4. $\quad$ The man who had been beside me was of the land

Collocation is an important part of the analysis of a writer's style from a stylistic perspective. As a result, Collocation provides information not just about the environment or story's main concepts but also about the author's cognitive structure. The most noticeable feature of Mowat's approach is his ability to experiment with language. He appears to be an extremely creative writer on the basis of his extensive usage of lexical patterns and phrases in his literary expression. E.g. the opening paragraph of Chapter-1 in People of the Deer,

On a morning in May of 1947 I boarded the train and gave myself up to the demands of the fever that was in me. My preparations for the journey were simple in the extreme. A visit to a War Assets store had provided me with an assortment of old army clothing and a cheap sleeping bag. I already owned a camera of the snapshot variety and this, together with my binoculars and a dozen rolls of film, completed my scientific equipment. For weapons, I took only the American carbine I had carried all through the war. (Mowat1)

Indeed, Mowat's linguistic ability in constructing such collocations is remarkable. He is 
not inventing new words to add to the English lexicon; rather, he is giving new meanings to terms that have been in the dictionary for a long time.

Mowat employs the profound words in a fresh way. Beyond that, Mowat's fictions are filled with brilliant coinages and collocations. In the story, he has chosen the most relevant phrases and constructions, resulting in a style that is both coherent and cohesive. In his style, one can see a strong reflection of both the ideas of stylistics - "style as a choice." and "style as deviation".

Mowat is a significant writer whose comprehensive perspective adds to the societal concepts of life, protection, and togetherness. His idea is not the most recent or remarkable, but the technique or style in which he communicates it is. Furthermore, his style does not become boring or repetitive. It is straightforward and polite. The sentences are composed in a clear and precise manner. It is independent of common blunders.

The author's idea and portrayal of the perspective correspond with the expectations of the readership, and a suitable relationship between both the author and the reader is produced with the assistance of the elegant style. According to this article based on the preceding stylistic research of Mowat's. He is a storyteller, environmentalist, historian, travel writer, activist, and, above all, an author of a different order, as seen by his astonishing range of topics and styles. However, considering his writings exhibit a strong linguistic consciousness, his narratives need a thorough stylistic examination. Indeed, his style, which is extremely poetic, distinctive, unusual, and abundantly communicable, is one of the primary elements in his phenomenal success as a writer who has made his influence on a huge audience around the world.

Therefore, it is appropriate to claim that Mowat is a master of verbal art and has an excellent command of vocabulary, syntax, and connotations when considering the competent use of words and varied verbal patterns. He appears to be a devout follower of the Environment's language. The points mentioned in the article would help the students of language and literature with the specified tools to explore a number of distinctive options of language. Hence, the study makes it straightforward to the scholars furthermore for the academics to grasp the literature through stylistic devices.

\section{References}

Abraham, M.H \& Harpham, G.G. (2009). A Handbook of Literary Terms. New Delhi, India.

Barry, Peter. (2013). "Beginning Theory" An Introduction to Literary and Cultural Theory, Viva Books, New Delhi.

Crystal. D \& Davy. D. (1969). Investigating English Style. Longmans Co., London.

Enkvist, Nils Erik.(1973). “Does Style Exist?” Linguistics Stylististics, Mouton Hague, Paris.

Gregory, Michael. (1964). Linguistics and Style, Oxford University Press, London.

Hendricks, O' William. (1971). Grammar of Style and Styles of Grammar, Andre Deutsch Ltd., Matthews, H.P. (2007). Concise Dictionary of Linguistics ( $2^{\text {nd }}$ Ed.), Oxford Uni. Press, Britain.

Mowat, Farley. (1975). People of the Deer, Douglas \& McIntyre Publishers. Canada. Middleton Murry. (1961- 65). The Meaning of Style, Oxford University Press, London, Sastri, M.I. (2001).

Stylistics "Linguistics and Literature", ed. V. Prakasam, CIFEL: Hyderabad.

$</ /$ archive.org/details/theoryofliteratu00inwell/page/n5/mode/2up $>$

$\langle/ /$ www.goodreads.com/book/show/28505190-linguistics-and-poetics $>$

$</ /$ archive.org/details/styleinlanguage00sebe/page/n17/mode/2up $>$ 